\title{
Using Crumb of Tyres in Hot Asphalt Mixture as Part of Aggregate
}

\author{
T. M. A. Al-Ani* \\ alanitaher@yahoo.com \\ W. M. Mahmood"
}

\author{
Th. Y. Ahmed" \\ th9mir@yahoo.com \\ S. M. A. Al-Ani
}

*MSc Anbar **BSc. (Researcher). / University/Engineering College/Civil Department

\section{Abstract}

This study have used crumb of tyres in asphalt mixture as apart of aggregate. Three sizes of grade of crumb tyres were used in asphalt mixture (No. 4 (4.75 mm), No. $8(2.36) \mathrm{mm}$ and No. $50(300 \mu \mathrm{mm}))$. Three percentages of asphalt cement $(4,5$ and 6$)$ by weight with three percentages of crumb tyres $(2,4$ and 8$) \%$ by weight were used with aggregates for preparing asphalt mixture specimens. Asphalt mixture specimens were prepared according to Marshall methods ASTM (D-1559). Thirty six specimens were prepared for evaluating Marshall properties (Marshall stability and flow, air voids percentage, bulk density, maximum bulk density, and Marshall Stiffness). Indirect Tensile Strength test (ITS) ASTM (D-1075) at $2^{\circ} \mathrm{C}$ has been used for evaluating resistance of asphalt mixture for cracking. For this purpose twenty four specimens were prepared for evaluating cracking resistance of asphalt mixture contain crumb tyres as part of aggregates. The study showed that the crumb of tyres has more effects on the performance of asphalt mixture by increasing the Marshall stability, flow, air voids, and decreasing bulk density and indirect tensile strength.

Keywords: asphalt mixture performance, Crumb of Tyres, Indirect Tensile Strength, Marshall performance.

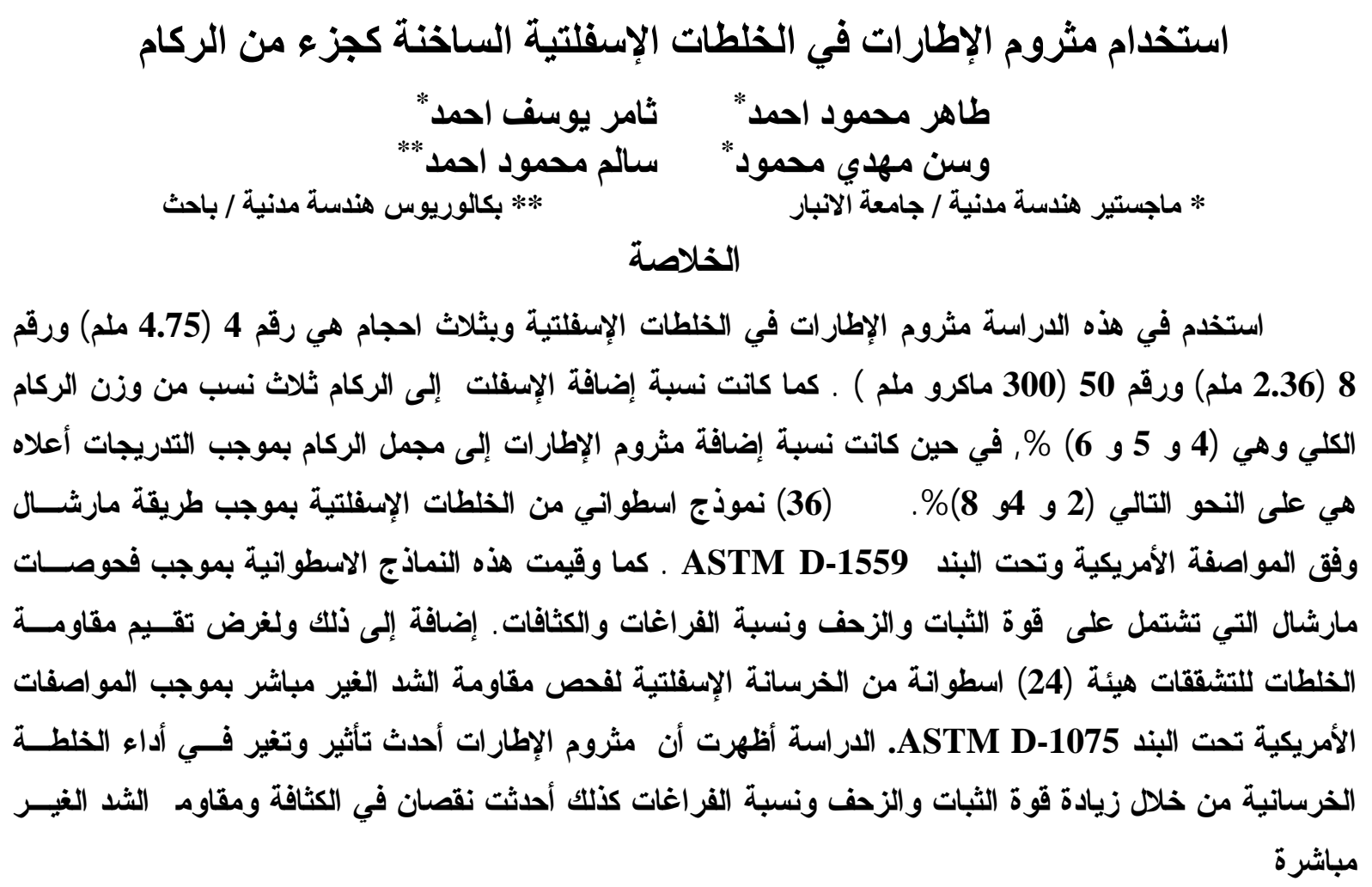

الخلاصة

استخدم في هذه الدراسة مشروم الإطارات في الخلطات الإسفلتية وبثلاث احجام هي رقم 4 (4.75 ملم) ورقم

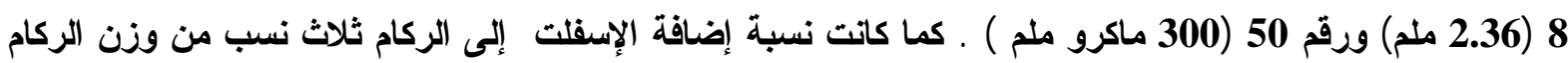

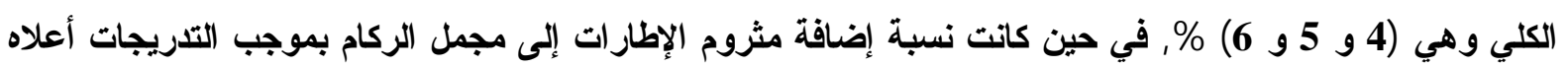

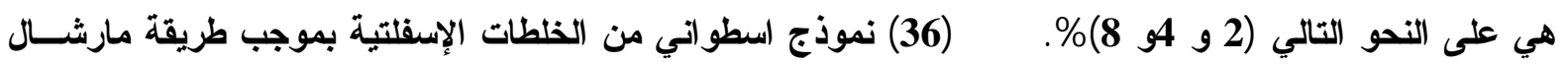
وفق المو اصفة الأمريكية وتحت البند

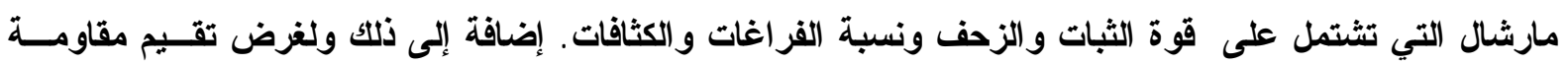

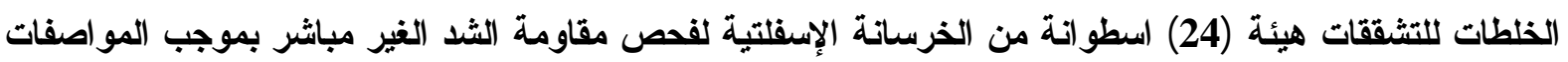

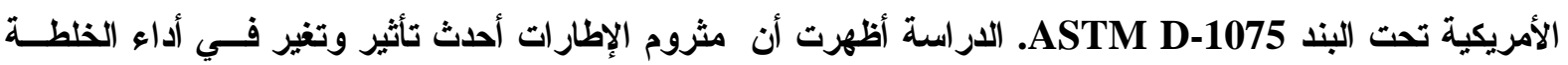
الخرسانية من خلا زيادة قوة الثبات والزحف ونسبة الفراغات كذلك أحدثت نقصان في الكثافة ومقاومة الثثد الغيـر 


\section{Introduction}

The nation faces a major ecological problem due to an accumulation of automobile waste and truck tires. Environmental regulations prohibit the open burning or burying of tires is solid waste facility. These tires are accumulating at the rate of about (3/4) billion per year [1],[2] and [3].

There are approximately 270 million waste tires generated annually in the United State of these, 230 million are passenger car tires and (40) million are truck tires [4].

A typical scrap tire (passenger car) weights approximately (9) kilograms and will provide approximately $(60 \%)$ rubber , $(20 \%)$ fiber and other waste products [5]. The paving industry uses $(1-2)$ million tires per year. Each metric ton of hot mix asphalt containing rubber can utilize $(2$ - 6) tires [6].

The purpose of modification include: increase the viscosity at high temperature, increase the flexibility and elasticity of binders at low temperature, improve the adhesion to aggregates, and improve high thermostability and aging resistance [7].

The aim of this paper is to study the effect of crumb rubber as part of aggregate on the performance of asphalt mixture for different percentage of adding (2\%, $4 \%$ and $8 \%$ ) by weight of aggregate. For this purpose the performance changes were evaluated by Marshall tests and Indirect Tensile Strength test at $25^{\circ} \mathrm{C}$.

\section{Review of literature}

Dr. Yusif M. and et.al [8], evaluated the effect of coarse and fine rubber particles on rutting performance of hot asphalt mixture (HAM). The coarse rubber particles exhibit increased rutting resistance as percentage of rubber increase up to (3.5\%). On the other hand crumb rubber dissolved in the binder and stiffened to increase it's rutting resistance. Even though only up to $(2.5 \%)$ coarse rubber particles could be used as compared to (15\%) of crumb rubber.

Rubberized asphalts resisted rutting better than conventional (unmodified) asphalt as will as polymer modified binder asphalts. Wheel tracking performance was similar for dry and wet mix asphalts, but fatigue life for dry mix was three times as long as that of wet mixes. Rubber crumb used to make binder not to affect wheel track very much, but had a significant effect on fatigue resistance. [9].

Result study on cores of asphalt rubber mixtures indicated higher wet indirect tensile strength and tensile strength ratios than the control mixture. In addition, the result of friction testing indicates that the rubberized mixture is performing better than the control mixture. [10].

Sarsam [11] used scrub tires with used oil and detergent for manufacturing recycling agent for asphalt concrete mixture in two grades of aggregate dense and gap gradation. The recycling causes Marshall Stability to increase especially for gap graded mixes; flow and Hveem Cohesion returned to their original values before aging.

Powder rubber or polymers should be added to AC-30 to form the binder used in asphalt bases. The resulting structural coefficient (a-value) for the powder rubber base is (0.45) compared to (0.40) for conventional base coarse using AC-30, addition of the powder rubber increases the cost of the binder (10\%) only while increasing its coefficient by $(12.5 \%)$ [12].

Many studies have reported that crumb rubber modifier (CRM) binders can produce asphalt pavements that exhibit increased pavement life, decreased traffic noise, reduced maintenance costs and resistance to rutting and cracking [13],[14] and [15]. 


\section{Materials and tests}

\subsection{Asphalt cement}

All data presented in this study had been collected in The Road Laboratory of Civil Engineering Department in Anbar University. One binder of asphalt cement was tested, from Daurah Refinery with a grade of (40-50) penetration. The physical properties (according to ASTM specification) of this type are illustrated in table (1).

Table (1). Physical Properties of Asphalt Cement.

\begin{tabular}{|c|c|c|}
\hline Test & Unit & $\begin{array}{c}\text { Daurah (40- } \\
50)\end{array}$ \\
\hline Penetration at 25 C & $\mathbf{0 . 1}$ mm & 45 \\
\hline Ductility at 25 C & $\begin{array}{c}\text { Centimete } \\
\text { r }\end{array}$ & $100+$ \\
\hline Softening Point & $\mathbf{C}^{\mathbf{o}}$ & 50 \\
\hline Flash Point & $\mathbf{C}^{\mathbf{o}}$ & 339 \\
\hline Specific Gravity & --- & 1.033 \\
\hline Kinematic Viscosity & cst. & $\mathbf{2 7 0}$ \\
\hline
\end{tabular}

\subsection{Aggregate (coarse and fine materials)}

Crushed aggregates are used in this work with a fixed dense gradation for all the specimens and from Al-Jaraishe quarry. The middle limits of the $(19 \mathrm{~mm})$ size dense gradation has been selected as a basic gradation in accordance with (ASTM D-3515) as shown in Figure (1)

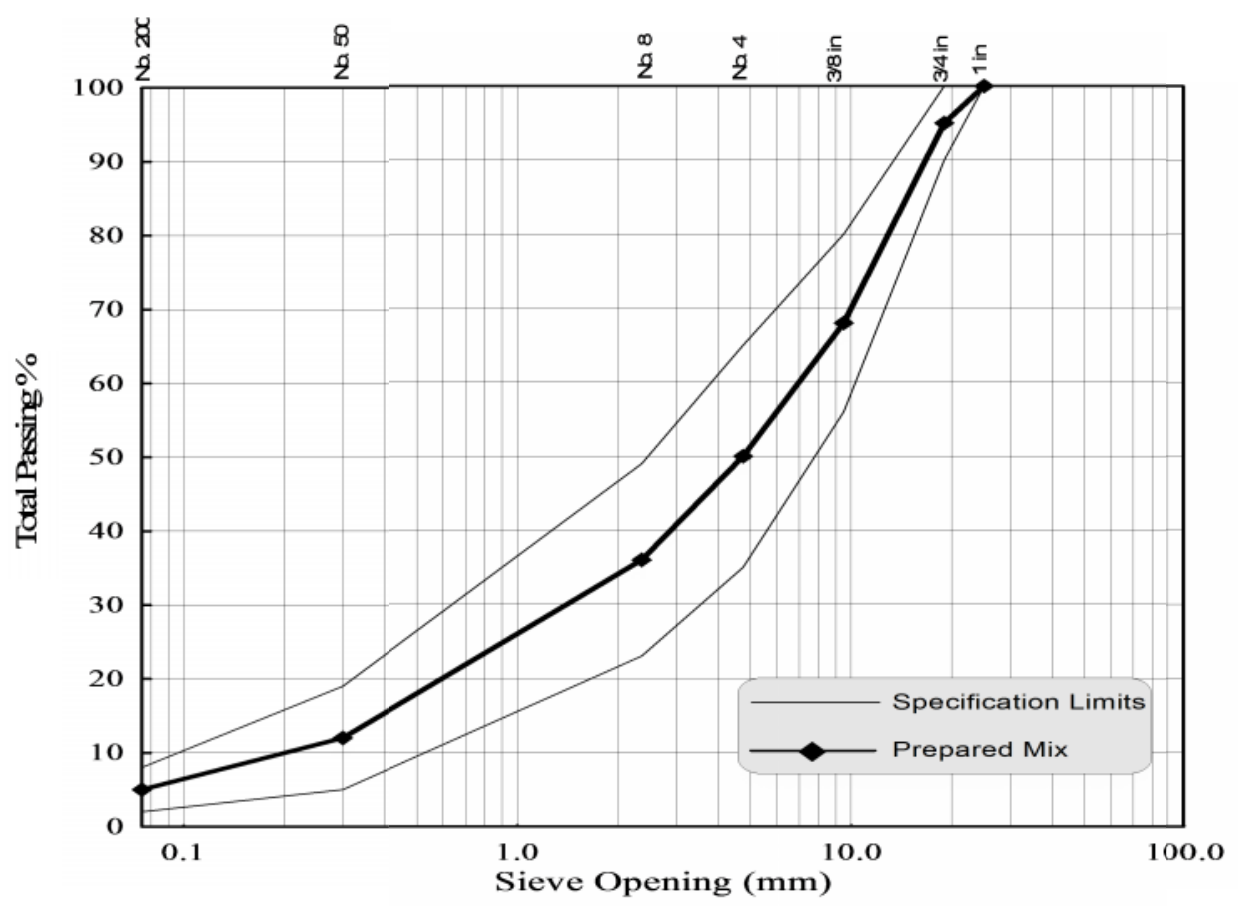

Figure (1). Specification Limits and Selected Gradation of Aggregate Maximum Size (19 mm) 


\subsection{Crumb of tyres}

Crumb of tyres was prepared by crushing, and grinding used tyres to small pieces about $(3 \times 3) \mathrm{cm}$, and using Nitrogen containers where the small pieces of tyres are put for (45 seconds) and crushing these freezing particles by using Marshall's hammer to produce crumb of tyres. The crumb of tyres was sieved to the sizes required. Figure (2), shows crumb of tyres after freezing and crushing. Sieve analysis of crumb of tyres is shown in Table (2).

Table (2). Properties of Crumb of Tyres.

\begin{tabular}{|c|c|}
\hline Sieve size $(\mathrm{mm})$ & \% Passing \\
\hline 9.5 & 100 \\
\hline No.4 $(4,75)$ & 67 \\
\hline No.8 $(2.36)$ & 32 \\
\hline No.50 (0.3) & 11 \\
\hline No. 200 (0.075) & 3 \\
\hline Specific Gravity & 1.237 \\
\hline
\end{tabular}

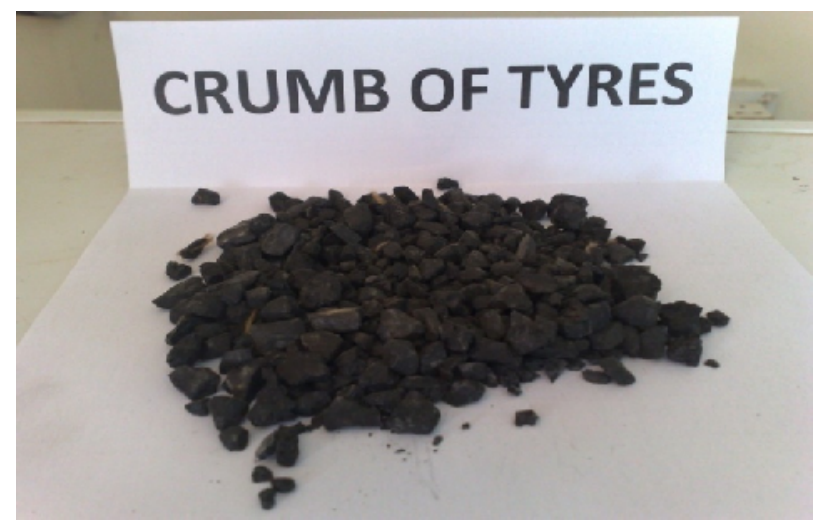

Figure (2). Crumb of Tyres Particles AfterFree and Crushing.

\subsection{Mineral filler}

One type of filler is used in this work which was Limestone dust obtained from Karbala Factory.

\subsection{Test methods} mixture:

The following tests were used in this work to evaluate the asphalt concrete

1. resistance to plastic flow (Marshall Stiffness) at $\left(60^{\circ} \mathrm{C}\right)$.

2. Indirect Tensile Strength (ITS) at $\left(25^{\circ} \mathrm{C}\right)$.

\subsection{Preparation of mixtures}

The aggregates were first dried to constant weight at $\left(110^{\circ} \mathrm{C}\right)$, separated into the desired sizes and recombined with mineral filler in order to meet the required gradation for each specimen. The aggregates were then heated to a temperature of $\left(155^{\circ} \mathrm{C}\right)$ before mixing with asphalt cement. The asphalt cement is heated to a temperature, which produces a kinematic viscosity of $(170 \pm 20)$ centistokes up to $\left(163^{\circ} \mathrm{C}\right)$ as an upper limit. Then, asphalt cement was weighted to desired amount, added to the heated aggregates, and mixed thoroughly until all aggregate particles were coated with asphalt binder.

\subsection{Preparation of asphalt mixture containing crumb of tyres}

To prepare one sample of aggregates containing crumb of tyres, calculate weight of each grade size tires of (No.4), (No. 8) and (No. 50) were prepared according to added percentage of $(2,4$, and 8$) \%$ by weight. After mixing the three sizes were stored in other container for final heating and mixing with aggregates. The total weight of crumb of tyres was reduced from the weight of aggregate for each selected sizes. The combined aggregates was put in the oven for heating to the temperature of mixing. 
Before mixing the aggregate with asphalt, and the combined crumb of tyres were put in oven for (15) minutes and after that added to the combined aggregate then the asphalt binder was added for mixing together.

\subsection{Resistance to plastic flow (Marshal method)}

This method covers the measurement of the resistance to plastic flow of cylindrical specimens of bituminous paving mixture loaded on the lateral surface by means of the Marshall apparatus according to (ASTM D-1559). The test specimens were compacted using one compact effort, which is (75) blows each surface. The bulk specific gravity density (ASTM D-2726), theoretical (maximum) specific gravity (ASTM D-2041) and percent air voids (ASTM D-3203) are determined for each specimen. Marshall Stability and flow tests were performed on each specimen according to the method described by (ASTM D-1559). The cylindrical specimens $(2.5 "(62.5 \mathrm{~mm})$ height * 4" $(101.6 \mathrm{~mm})$ diameter) were compressed on lateral surface with a constant rate of $(50.8 \mathrm{~mm} / \mathrm{min})$ until the maximum load was reached. The maximum load resistance and corresponding flow values were recorded. Three specimens for each combination were prepared and the average results were reported.

\subsection{Indirect tensile strength test}

The same methods illustrated in items (6.1. and 6.2.) were used for preparing (24) samples for Indirect Tensile Strength test (ITS) according to (ASTM D-4123). The specimens were left to cool at room temperature for 24 hours, immersed in a water bath at $25^{\circ} \mathrm{C}$ for 30 minutes, then tested for ITS at rate of $50.8 \mathrm{~mm} / \mathrm{min}$. ( $2 \mathrm{in} / \mathrm{min}$ ) in a compression machine until recording the ultimate load resistance.

Equation (1) used for calculating the indirect tensile strength after testing the specimens is [16].

$\mathrm{ITS}=2 \mathrm{P} / \pi \mathrm{T} \mathrm{D}$

Where:-

ITS $=$ indirect tensile strength (calculated for three specimens). $\mathrm{N} / \mathrm{mm}^{2}$.

$\mathrm{P}=$ Ultimate applied load required to fail specimens $(\mathrm{N})$.

$\mathrm{T}=$ Thickness of specimen, $\mathrm{mm}$

$\mathrm{D}=$ Diameter of specimen, $\mathrm{mm}$

\section{Results and Discussion}

The data of study are presented in Table (3) and Table (4).

Table (3). Marshall Properties of Asphalt Mixture.

\begin{tabular}{|c|c|c|c|c|c|c|c|c|c|c|c|c|c|c|c|c|}
\hline \multirow{3}{*}{ No } & \multirow{3}{*}{ 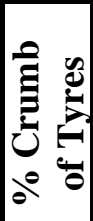 } & \multirow{2}{*}{\multicolumn{3}{|c|}{$\begin{array}{c}\text { Stability kN } \\
\% \text { asphalt } \\
\end{array}$}} & \multirow{2}{*}{\multicolumn{3}{|c|}{$\begin{array}{l}\text { Flow mm } \\
\% \text { asphalt }\end{array}$}} & \multicolumn{3}{|c|}{$\begin{array}{l}\% \text { Air } \\
\text { voids }\end{array}$} & \multicolumn{3}{|c|}{$\begin{array}{c}\text { Theoretical } \\
\text { Density }\end{array}$} & \multicolumn{3}{|c|}{$\begin{array}{c}\text { Bulk density } \\
\mathrm{gm} / \mathrm{cm}^{3}\end{array}$} \\
\hline & & & & & & & & \multicolumn{3}{|c|}{$\%$ asphalt } & \multicolumn{3}{|c|}{$\%$ asphalt } & \multicolumn{3}{|c|}{$\%$ asphalt } \\
\hline & & 4 & 5 & 6 & 4 & $=$ & 6 & 4 & 5 & 6 & 4 & 5 & 6 & 4 & 5 & 6 \\
\hline 1. & 0 & 9.45 & & 6.63 & 2.7 & 3.2 & 4 & 3.8 & 2.4 & 1.9 & 2.49 & 2.46 & 2.42 & 2.397 & 2.406 & 2.374 \\
\hline 2. & 2 & 1 & 9.8 & 9.52 & 4.9 & 5.8 & 6.7 & 6.9 & 3.8 & 2.8 & 2.483 & 2.429 & 2.393 & 2.328 & 2.349 & 2.34 \\
\hline 3. & 4 & & 95 & 7.8 & 5.6 & 6.6 & 7.1 & 7.8 & 6 & 4.3 & 2.447 & 2.414 & 2.3 & 2.269 & 2.283 & 2.298 \\
\hline 4. & 8 & 6.95 & 6.37 & 5.8 & 6.8 & 7.3 & 8 & 8.8 & 6.4 & 5.6 & 2.396 & 2.351 & 2.335 & 2.198 & 2.215 & 2.19 \\
\hline
\end{tabular}


Table (4). Indirect Tensile Strength Properties of Asphalt Mixture.

\begin{tabular}{|c|c|c|c|c|}
\hline \multirow{2}{*}{ No } & \multirow{2}{*}{$\begin{array}{c}\text { \% Crumb } \\
\text { of Tyres }\end{array}$} & \multicolumn{3}{|c|}{ ITS N/mm } \\
\cline { 3 - 5 } & & 4 & 5 & 6 \\
\cline { 3 - 5 } & & 0.993 & 0.744 & 0.718 \\
\hline 1. & 0 & 0.684 & 0.813 & 0.503 \\
\hline 2. & 2 & 0.727 & 0.684 & 0.624 \\
\hline 3. & 4 & 0.856 & 0.521 & 0.607 \\
\hline 4. & 8 & & & \\
\hline
\end{tabular}

According to the asphalt-rubber concrete mixes tested at the specifications followed the result obtained are:-

Figure (3) shows the effect of crumb of tyres on Marshall Stability at different asphalt contents. Stability increases with increasing Crumb of Tyres content until (2\%) after that, there is reduction in the stability. At $(4 \%)$ the stability remained near the original value but, at $(8 \%)$ the stability became less than original value.

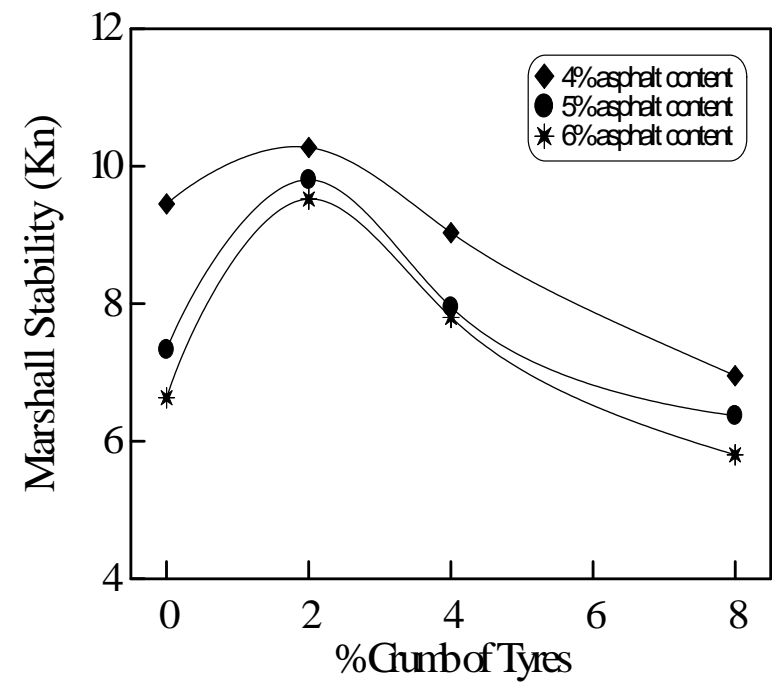

Figure (3). Effect of Crumb of Tyres Contents on Marshall Stability of Asphalt Mixture at Different Asphalt Contents

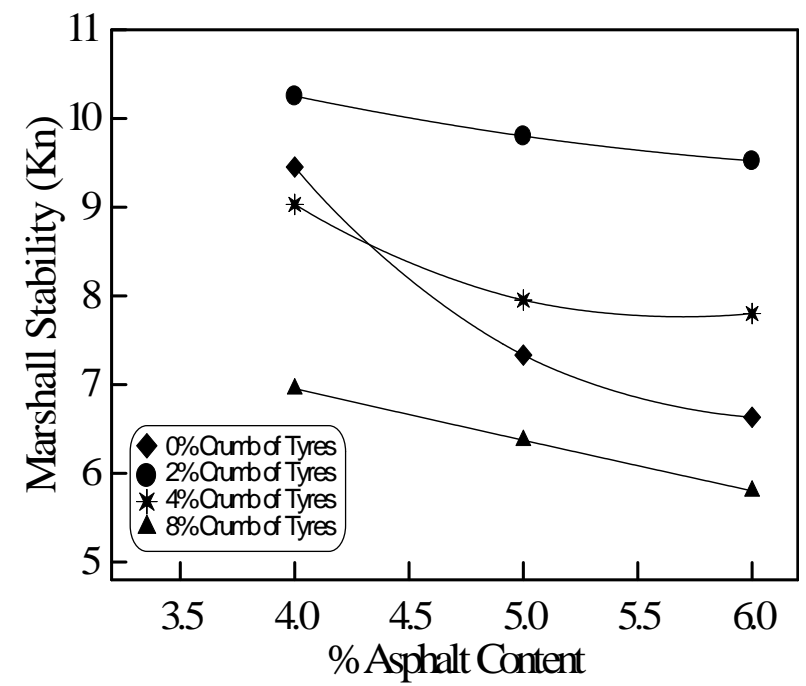

Figure (4). Effect of Asphalt Content on Marshall Stability of Asphalt Mixture at Different Contents of Crumb of Tyres.

Figure (4) shows the effect of asphalt content on Marshall Stability at different crumb of tyres contents. Stability decreases with increasing asphalt content but, the rate of decreasing with crumb of tyres content is lower compared with the original mixture.

Figure (5) shows the effect of crumb of tyres on Marshall flow. The flow increases with increasing in crumb of tyres contents. The percent of increase at $(2 \%)$ is about $(75 \%)$ more than the original value. It increased gradually until it reached to more than $(100 \%)$ as compared to the original value. To explain this behavior, the Marshall flow with crumb of tyres was composed of deformations among the particles of aggregate and the deformations in the crumb of Tyres particles, while in original mixture the deformations was among the particles of aggregate only. 


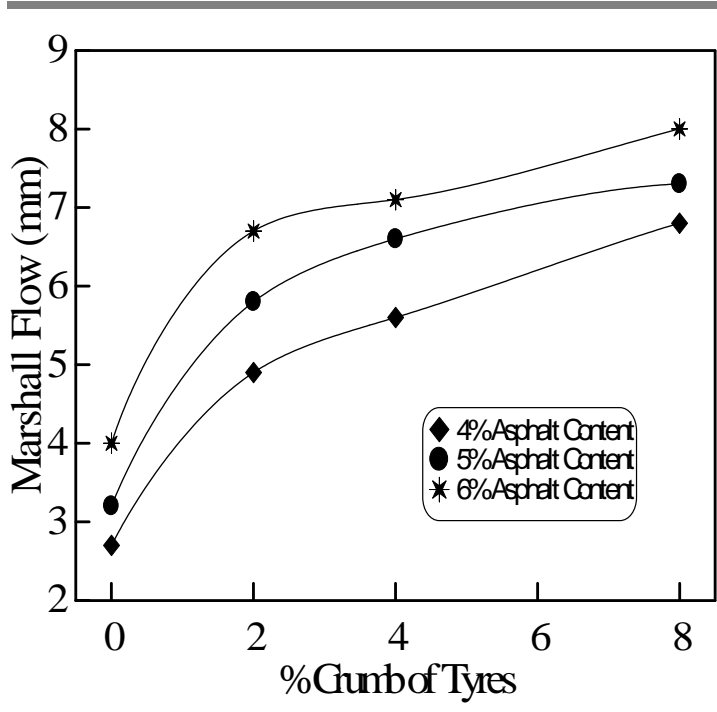

Figure (5). Effect of Crumb of Tyres

Contents on Marshall Flow of Asphalt Mixture at Different Asphalt Contents.

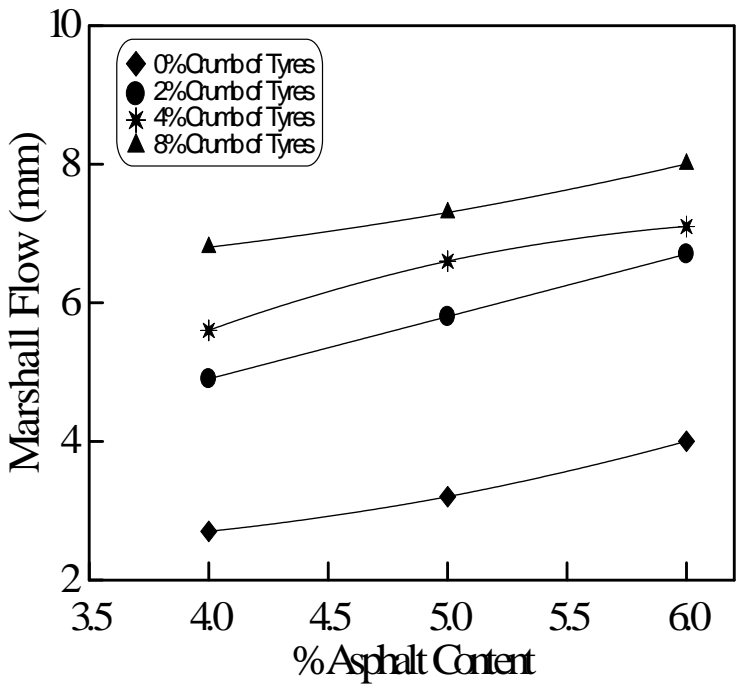

Figure (6). Effect of Asphalt Content on Marshall Flow of Asphalt Mixture at Different Contents of Crumb of Tyres

Figure (6) shows the effect of asphalt contents on Marshall tlow at ditterent crumb of tyres contents. The flow increases with increasing the asphalt content for different crumb of tyres content. The flow increases with increasing Crumb of Tyres contents.

Figure (7) shows the effect of Crumb of Tyres on Marshall stiffness. Where:-

Marshall Stiffness $=($ Marshall Stability $/$ Marshall Flow $)(\mathrm{kN} / \mathrm{mm})$

Marshall Stiffness decreases with increasing crumb of tyres contents. The rate of variance decreased with increasing crumb of tyres content. This result is natural because the flow increases with increasing the crumb of tyres contents.

Figure (8) shows the effect of asphalt contents on Marshall stiffness for different crumb of tyres contents. The rate of variance in Marshall Stiffness decreases with increasing crumb of tyres contents where, the rate of change in Marshall Stiffness for the original mixture is higher than mixture content crumb of tyres contents.

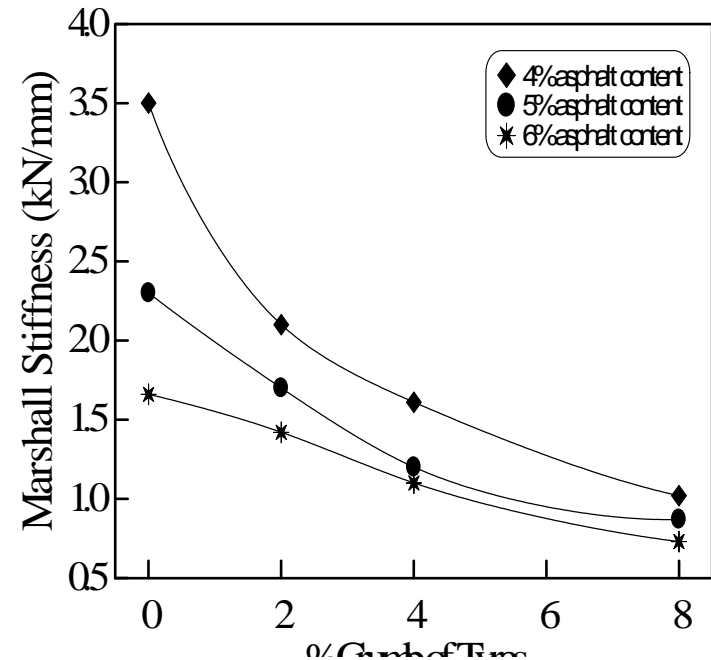

Figure (7). Effect of Crumb of Tyres Contents on Marshall Stiffness of Asphalt Mixture at Different Asphalt Contents

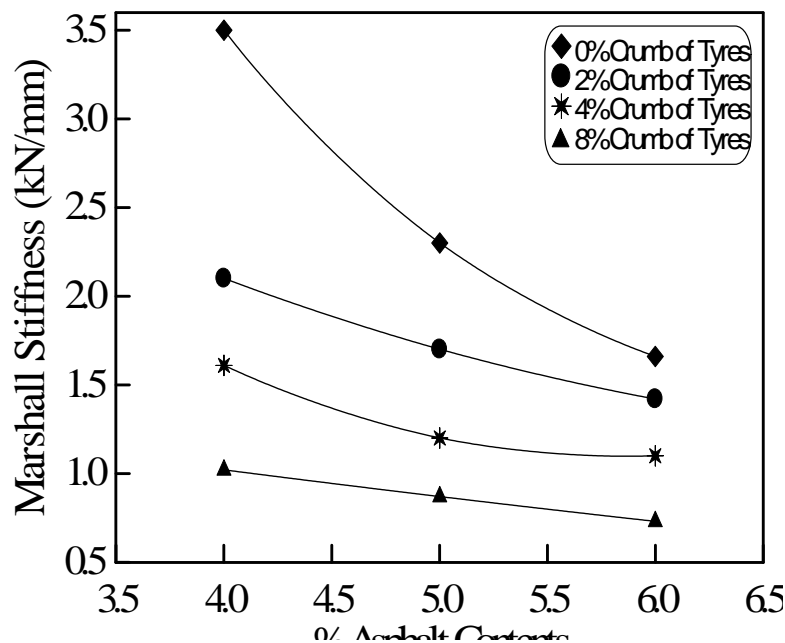

Figure (8). Effect of Asphalt Contents on Marshall Stiffness of

Asphalt Mixture at Different Crumb of Tyres Contents. 
Figure (9) shows the effect of crumb of tyres contents on maximum density. The crumb of tyres content has significant effect on maximum density because the specific gravity of crumb of tyres is less than the specific gravity of aggregate.

Figure (10) shows the effect of asphalt content on maximum density for different crumb of tyres contents. There is decrease in maximum density with increasing asphalt contents.

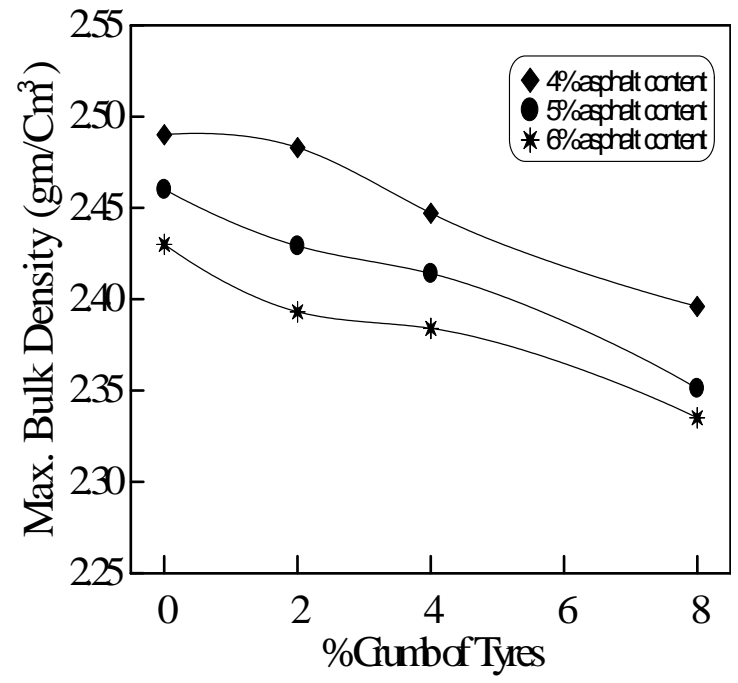

Figure (9). Effect of Crumb of Tyres Contents on Max. Density of Asphalt Mixture at Different of Asphalt Contents

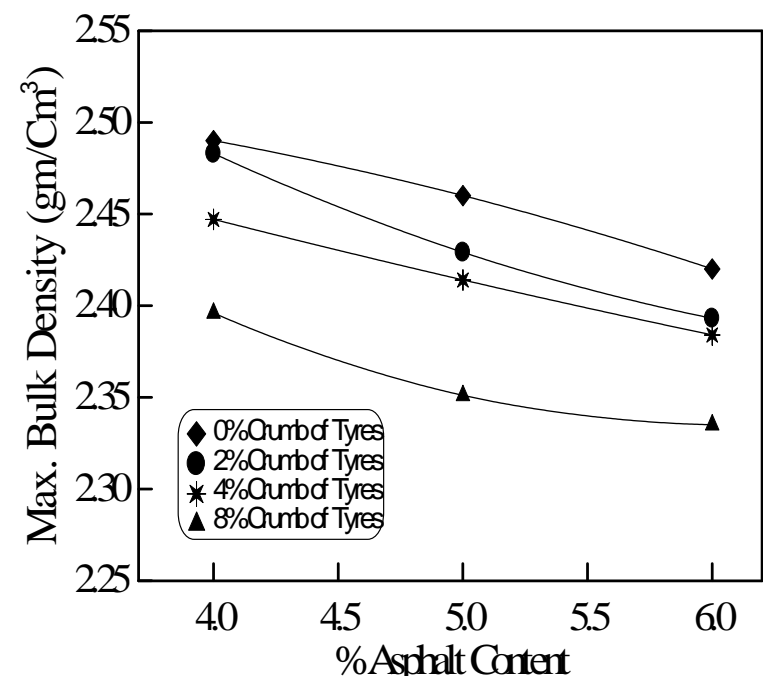

Figure (10). Effect of Asphalt Content on Max. Density of Asphalt Mixture at Different Crumb of Tyres Contents.

Figure (11) shows the effect of crumb of tyres contents on bulk density of mixture. The crumb of tyres contents has significant effect on bulk density. By increasing the crumb of tyres contents the bulk density of mixture decreases because the specific gravity of crumb of tyres is less than specific gravity of aggregate and will operate larger volume as compared to the same weight of aggregate.

Figure (12) shows the effect of asphalt contents on bulk density of mixture for different crumb of tyres contents. The variance in asphalt contents hasn't significant effect on the bulk density of mixture for different crumb of tyres contents.

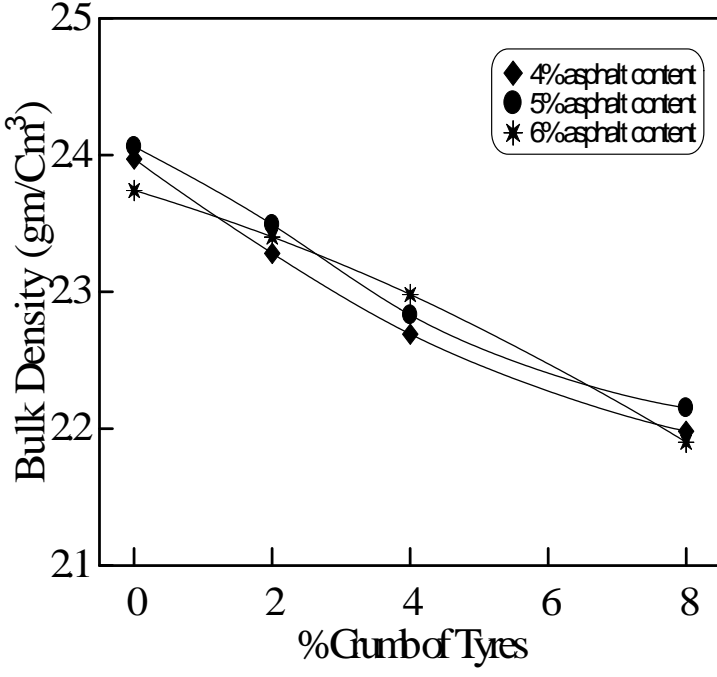

Figure (11). Effect of Crumb of Tyres Contents on Bulk Densityof Asphalt Mixture at Different Asphalt Contents.

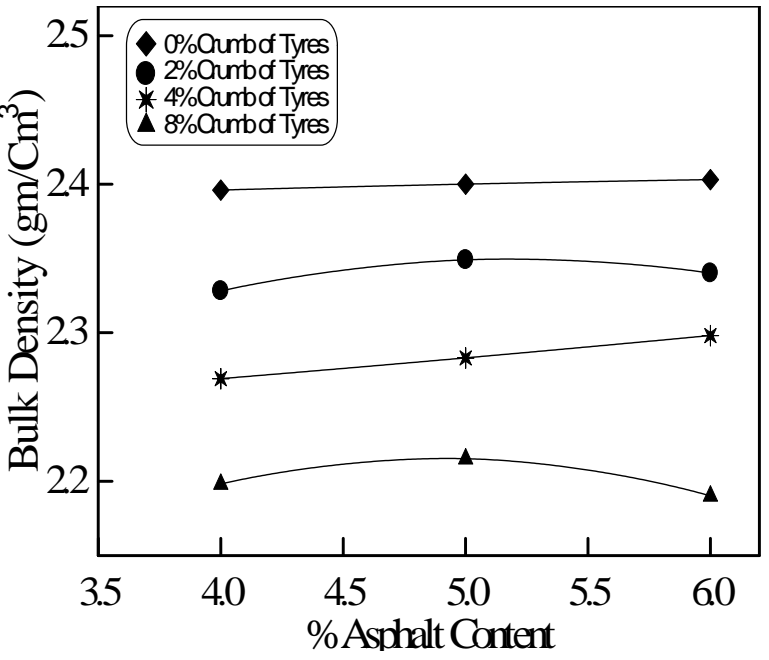

Figure (12) Effect of Asphalt Content on Bulk Density of Asphalt Mixture at Different Content of Crumb of Tyres . 
Figure (13) shows the effect of crumb of tyres contents on the percentage of air voids in mixture. Air voids increase with increasing of crumb of tyres contents because crumb of tyres have specific gravity less than the specific gravity of the aggregate. On the other hand, the combined aggregate with crumb of tyres particles has surface area grater than pure aggregate Therefore, percent of air voids increase with increasing crumb of tyres contents.

Figure (14) shows the effect of asphalt content on the percentage of air voids in mixture for different crumb of tyres content. Air voids decrease with increasing of asphalt content.

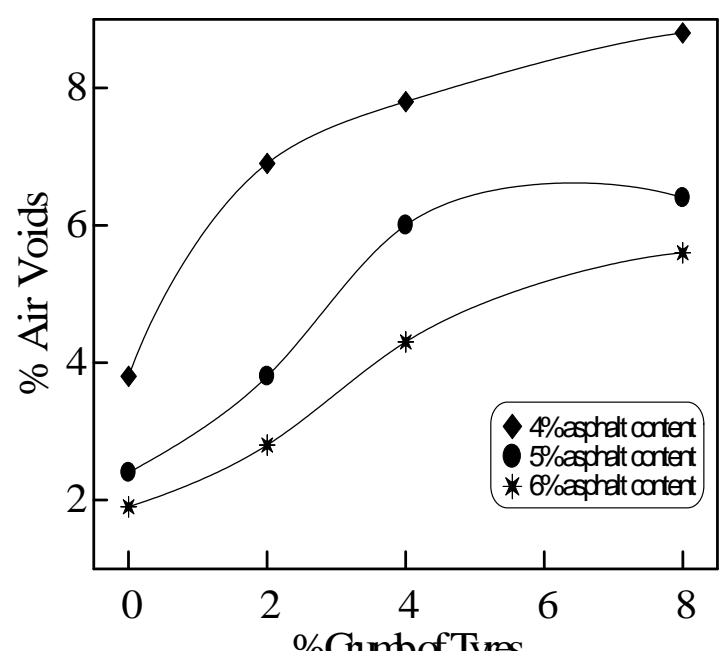

Figure (13) Effect of Crumb of Tyres Contents on Air Voidsof Asphalt Mixture at Different Asphalt Contents

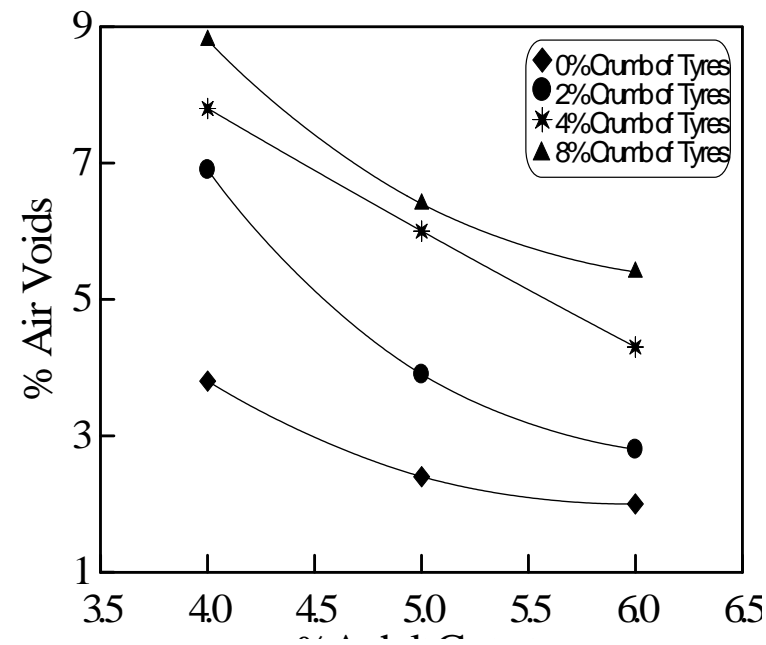

Figure (14) Effect of Asphalt Contents on Air Voids of Asphalt Mixture at Different Contents of Crumb of Tyres.

Figure (15) is a Histogram showing the effect of crumb of tyres on the Indirect Tensile Strength (ITS) of asphalt mixture at different asphalt contents. The behavior of the variations gradually decreases at $(0$ and 4$) \%$ of crumb of tyres additive with increasing asphalt contents. Variations at other percents of added crumb of tyres take random behavior.

Figure (16) is a Histogram showing the effect of asphalt contents on the Indirect Tensile Strength (ITS) of asphalt mixture at different crumb of tyres contents. The behavior of the variations for the (ITS) at (4 and 6)\% of asphalt contents increases with increasing the crump of tyres contents but, the percent of reduction in (ITS) as compared to original mixture ( $0 \%$ crump of tyres), is about (10\% to 30\%). At asphalt content $(5 \%)$ (ITS) decreases with increasing crumb of tyres contents, but the original mixture ( $0 \%$ crump of tyres) is less than ( $2 \%$ crump of tyres). 


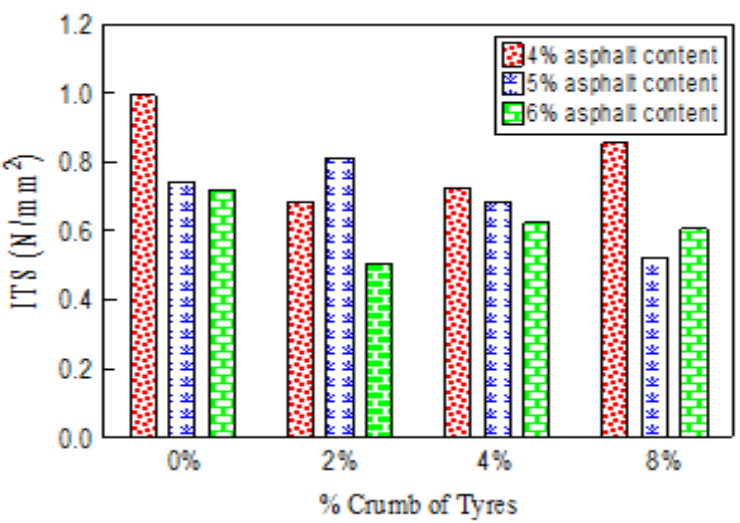

Figure (15) Effect of Crumb of Tyres Contents on Indirect Tensile Strength of Asphalt Mixture at Different Asphalt Contents

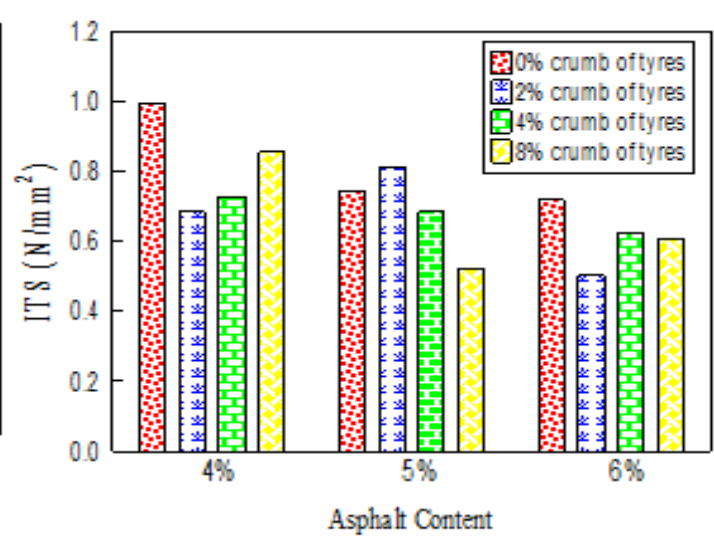

Figure (16) Effect of Asphalt Contents on Indirect Tensile Strength of Asphalt Mixture at Different Crumb of Tyres Contents

\section{Conclusions and Recommendations:-}

The study shows that the utilization of crumb of tyres has more effect on asphalt mixture performance as follow:-

\subsection{Conclusions}

1. Increasing in the Marshall stability until (2\%) Crumb of Tyres content, and reduction in Stability after this percentage.

2. Increasing crumb of tyres causes increasing in Marshall Flow about $(75-100) \%$, and increasing in air voids content too more than original mixes.

3. The crumb of tyres additives caused decreasing in the bulk density of the asphalt mixture.

4. Increasing crumb of tyres causes reduction in indirect tensile strength about (10 to 30$) \%$ less than original mixtures.

\subsection{Recommendations:-}

1. Effect of crumb of tyres on asphalt mixture performance at high temperature, need to more study.

2. Effect of aging on the performance of asphalt mixture containing crumb of tyres is needed to be extensively investigated.

\section{References}

[1]Hunt, E.A. "Crumb Rubber Modified Asphalt Concrete In Oregon" Final Report: FHWA-OR-02-13, SPR 355,2001.

[2] Volle, T.H. "Performance Of Rubberized Asphalt Pavements In Illinois" Report No: FHWA/IL/PRR-136.2000.

[3]Oliver, J. W. "Rutting and Fatigue Properties Of Crumbed Rubber Hot Mix Asphalt", International Journal of Road Materials and Pavement Design Volume: 1 Issue: 2, 2000.

[4]"Engineering and Environmental Aspects of Recycled Materials for Highway Construction", Appendix 1," Western Research Institute, Publication No. FHWARD-93-088, June 1993. 
[5]S.N. Amirkhanian and L.C. Arnold "A laboratory and Field Investigation of Rubberized Asphaltic Concrete Mixtures (Pelham Road)," Clemson University. Report No. FHWA-SC-93-02, April1993.

[6]M.A. Heitzman "State of the Practice - Design and construction of Asphalt Paving Materials with Crumb Rubber Modifier" U.S. Department of Transportation, Federal Highway Administration, Publication No. FHWA-SA-92-022, May 1992.

[7]Ertman Larsen H. J.; Wohlk C.J. and Hall-Andersen B.,"Modified Bitumen" Proceeding of the Australian Road Research Board, Part 8, Volume 14, 1988, pp. 222-229.

[8]http://www.amp.ece.cmu.edu/Publication/Devi/Mehta_SWJ_2005.pdf

[9]American Society of Testing and Materials, 1994.

[10]Serji N. Amrikhanian, Ph.D. " Utilization of Crumb Rubber in Asphalt Concrete Mixture- South Carolina's Experience” Department of Civil Engineering Clemson University , January 2001.

[11]Saad Issa Sarsam "A Study On Aging and Recycling of Asphalt Concrete Pavement" University of Sharijah Journal of Pure and Applied Sciences, Volume 4, No. 2, June 2007.

[12]Freddy L. Roberts, T.L. James Louay N. Mohammed, Hanlin Qin, and Baoshan Huang "Comparative Performance of Rubber Modified Hot Mix Asphalt Under ALF Loading” LTRC, July 2004. Technical Summary Report 374.

[13]Ruth BE, Roque R. "Crumb Rubber Modifier (CRM) in Asphalt Pavements", Proceedings of the transportation congress, 1995. p.768-85.

[14]Liang RY, Lee S. "Short-term and long-term aging behavior of rubber modified asphalt paving mixtures", TRB 1996;1530:11-7.

[15]Huang B, Mohammad LN, Graves PS, Abadie C. Louisiana "Experience with crumb rubber-modified hot-mix asphalt pavement". TRB 2002;1789:p.p.1-13.

[16]Asal Farid Naom "Some Investigation Into The Properties Of Polymer Modified Asphalt Cement" Thesis , Department of Civil Engineering Baghdad University, November 1999, P 31. 